\title{
A systematic review of quality of life and weight gain-related issues in patients treated for severe and persistent mental disorders: focus on aripiprazole
}

\author{
Salvatore Gentile \\ Department of Mental Health, ASL \\ Salerno I, Italy
}

\begin{abstract}
Aripiprazole is a relatively novel second-generation antipsychotic belonging to the chemical class of benzisoxazole derivatives and is characterized by a unique pharmacological profile which suggests that the drug acts as a dopamine-serotonin system stabilizer. Whereas all previously available antipsychotics are antagonists at $\mathrm{D}_{2}$ receptors, aripiprazole is the only available partial agonist at these receptors. Thus, it has been suggested that aripiprazole could be associated with a relatively neutral impact on bodyweight, possibly reducing risks of a detrimental impact on the quality of life that often complicates management for a large number of patients diagnosed with severe and persistent mental disorders (SPMDs) treated chronically with antipsychotic medications. However, data from short- and long-term reviewed studies indicate that the prevalence rate of clinically relevant weight gain during therapy with this drug is similar to that occurring during treatments with other antipsychotic agents, either typical or atypical. Moreover, information on the impact of aripiprazole therapy on the quality of life of patients diagnosed with SPMDs is scarce and characterized by conflicting results. Given these results, further, large, well-designed studies are needed before confirming potential advantages of aripiprazole over first-generation antipsychotics and other SGAs.
\end{abstract}

Keywords: aripiprazole, effectiveness, quality of life, safety, weight gain

\section{Introduction}

Schizophrenia is a chronic and highly disabling psychiatric disorder estimated to affect approximately $1 \%$ of the general population worldwide; ${ }^{1,2}$ in the United States alone, the disorder affects more than 2.5 million people, and it costs an estimated US $\$ 40$ billion a year (including lost productivity). ${ }^{3}$ On the other hand, bipolar disorder is a lifelong illness characterized by recurrent manic, depressive, or mixed symptoms and episodes. ${ }^{4}$ Without adequate long-term treatment, bipolar disorder is associated with high rates of morbidity: ${ }^{5}$ it affects approximately $1.2 \%$ of the population (2.3 million adult Americans). ${ }^{6}$

In the last few years, second-generation antipsychotics (SGAs) have progressively become the first-line agents in the treatment of these severe and persistent mental disorders (SPMDs). This change in the historical pharmacological approach to such disorders has been mainly due to better neurological safety of this antipsychotic agents, less likely to induce serious adverse events (such as extrapyramidal reactions and tardive dyskinesia) than first-generation antipsychotics (FGAs). ${ }^{7}$ The improved tolerability shown by SGAs has been attributed to specific pharmacokinetic properties: whereas most of these agents evidence an antagonist activity at the $\mathrm{D}_{2}$ dopaminergic receptor subtypes comparable to that shown by FGAs, SGAs also have both specific antagonist properties at 5- $\mathrm{HT}_{2 \mathrm{AC}}$ serotoninergic receptor subtypes and partial agonist properties at $5-\mathrm{HT}_{1 \mathrm{~A}}$ subtypes; ${ }^{8}$ the potential importance of faster dissociation from the 
dopamine $\mathrm{D}_{2}$ receptor of these agents compared to FGAs in reducing the detrimental impact on central nervous system areas involved in regulating motor functions has been also highlighted..$^{9,10,11}$

Unfortunately, however, SGAs are not devoid of other severe adverse events, especially during long-term treatments: indeed, this class of drugs introduced onto the market in the mid-1990s has been associated with a wide range of other adverse reactions, such as hyperprolactinemia ${ }^{12}$ (which may lead to adverse sexual effects, including gynecomastia and galactorrhea), weight gain, diabetes mellitus, metabolic syndrome, ${ }^{13}$ and prolongation of corrected QT (QTc) interval on electrocardiograms (ECGs). ${ }^{14}$ All these adverse effects are associated with increased rates of treatment discontinuation and relevant long-term health risk. ${ }^{15,16}$ Therefore, the development of new SGAs characterized by a good profile of metabolic and cardiac tolerability is a coherent research direction in the quest for an optimal pharmacological management of SPMDs.

Aripiprazole is a relatively novel SGA belonging to the chemical class of benzisoxazole derivatives, characterized by a unique pharmacological profile (see Table 1) which suggests that the drug acts as a dopamine-serotonin system stabilizer. ${ }^{17}$ Most relevant, whereas all previously available antipsychotics are antagonists at $\mathrm{D}_{2}$ receptors, ${ }^{18}$ aripiprazole is the only available partial agonist at these receptors. ${ }^{19}$

It has been hypothesized that the relatively low affinity at $\mathrm{H}_{1}$ histaminergic receptor subtypes shown by aripiprazole could theoretically be associated with a relatively neutral impact on bodyweight. However, this finding remains controversial: ${ }^{13}$ for this reason, this review firstly aims to attempt to definitively assess this relevant clinical point.

Despite the still-open debate about the potential relationship between aripiprazole therapy and increased risks of

Table I Pharmacodynamic profile of aripiprazole $17,60,61,62,63,64,65,66$

\begin{tabular}{ll}
\hline Receptor subtype & Activity \\
\hline $\mathrm{D}_{2}$ & Partial agonist \\
$\mathrm{D}_{3}$ & Partial agonist \\
$\mathrm{D}_{4}$ & Partial agonist \\
$\mathrm{a}_{1}$-adrenergic & Antagonist \\
$\mathrm{H}_{1}$ & Antagonist \\
$5-\mathrm{HT}_{1 \mathrm{~A}}$ & Partial agonist \\
$5-\mathrm{HT}_{2 \mathrm{~A}}$ & Antagonist \\
$5-\mathrm{HT}_{2 B}$ & Inverse agonist \\
$5-\mathrm{HT}_{2 C}$ & Partial agonist \\
$5-\mathrm{HT}_{6}$ & Antagonist \\
$5-\mathrm{HT}_{7}$ & Antagonist \\
\hline
\end{tabular}

weight gain and other metabolic complications, ${ }^{13,20,21}$ it has been also stated that this specific facet of the safety profile of aripiprazole assumed on the basis of its peculiar pharmacodynamic characteristics may result in a decreased detrimental impact on the quality of life that often complicates management for a large number of patients diagnosed with SPMDs treated chronically with antipsychotic medications. ${ }^{22}$ Nonetheless, a large, long-term study has already demonstrated that there is no disadvantage in terms of quality of life and/or symptoms in using FGAs rather than some SGAs; ${ }^{23}$ however, this study did not include patients treated with aripiprazole. Thus, another aspect of the effectiveness of aripiprazole which needs to be clarified (the second, but not secondary, scope if this review) is if its unique pharmacological profile may truly result in the improvement of the quality of life of patients with SPMDs who necessitate short- or long-term therapy with this specific antipsychotic medication.

\section{Methods}

Electronic searches of Medline/PubMed, EMBASE, Current Contents, and PsycINFO from 1980 to October 2008 were conducted using the following key words: aripiprazole, schizophrenia, bipolar disorder, weight gain, quality of life (QOL). 146 studies were recognized. Inclusion criteria were represented by the articles which reported the prevalence of clinically relevant weight gain (defined as $\geq 7 \%$ increase from baseline) during either short- or long-term therapy with aripiprazole. Moreover, all trials which evaluated changes in quality of life in patients treated with aripiprazole were considered suitable for the scopes of this review. Hence, 131 articles were excluded whereas 15 studies meeting the first and/or the second inclusion criterion were reviewed.

\section{Results Weight gain}

Besides the well-known impact of overweight and obesity on physical health, both metabolic complications have also been associated with diminished self-esteem, amplified rates of non-compliance with treatment regimens and, thus, increased risks of symptomatologic relapse. ${ }^{24,25}$ Notwithstanding this background, it was not until 2005 that the SGA-associated risk of weight gain was analysed comprehensively. ${ }^{26}$ However, this analysis showed at least two limitations: the first is data being collected from short-term studies, despite SGAs are routinely utilized as treatment for chronic mental disorders; the second is that such results were prevalently based on manufacturer's data that had been used for preparing the US official labels of drugs. ${ }^{27}$ The first systematic 
review which provided original data on this topic became available only one year later: ${ }^{13}$ the main finding emerging from this appraisal was that the hypothesized differences among these agents in the liability of inducing weight gain decrease during long-term treatment. A second systematic review which approached the focus from an innovative point of view was published recently by Álvarez-Jiménez et al who concluded that, in patients with first psychotic episode, the true magnitude of the effect might have been underestimated. ${ }^{28}$ Unfortunately, however, despite growing awareness that studies investigating risk of weight gain during long-term treatment with SGAs have to be conducted in accordance with strict and rigorous methodological criteria, data on aripiprazole still suffer from quantitative and qualitative limitations.

\section{Short/medium-term studies on schizophrenic/schizoaffective patients}

A multicenter, double-blind, placebo-controlled, parallelgroup trial investigated the effectiveness of aripiprazole (20-30 mg/day, fixed doses) in in-patients with acute psychotic exacerbation. ${ }^{29}$ Patients prescribed aripiprazole were compared with two groups of patients receiving fixed doses (6 mg/day) of risperidone or placebo, respectively. In both active treatment groups, the rate of prevalence of clinically relevant weight gain ( $\geq 7 \%$ increase versus initial weight) was significantly higher than that shown by the placebo group. Regrettably, the study provided no information about potential differences in the liability of inducing weight gain between aripiprazole and risperidone. Moreover, this study was conducted on institutionalized patients who, presumably, were on fixed dietary regimen: for this reason, it is reasonable to assume that the prevalence rate of clinically relevant weight gain recorded in these patients could not reflect the rate recordable in a real world setting. In any case, in a subsequent study conducted on patients of specific ethnicity between these two SGAs, ${ }^{30}$ no differences were found in the liability for inducing weight gain. In a similarly designed study, the effectiveness of fixed doses of aripiprazole (15 and $30 \mathrm{mg}$ /day) was compared with placebo and $10 \mathrm{mg}$ /day of haloperidol. ${ }^{31}$ The study demonstrated that both active treatments were associated with a statistically significant increase in the incidence of clinically relevant weight gain compared with placebo. In fact, no statistically significant differences were found in the liability of inducing weight change between aripiprazole and haloperidol. A similar tendency to induce weight change was also found between aripiprazole and a different FGA, perphenazine, in a study performed on a population of patients diagnosed with treatment-resistant schizophrenia. ${ }^{32}$

A multicenter, randomized, naturalistic study compared the effectiveness of aripiprazole with the standard of care (SOC) in community-treated schizophrenic patients. ${ }^{33}$ In this study too, aripiprazole was not devoid of an intrinsic liability to induce clinically relevant weight changes. Moreover, despite it being found that a higher proportion of patients on SOC (including olanzapine, quetiapine, and risperidone) had clinically relevant weight gain compared with patients treated with aripiprazole, no information was provided about the eventual statistical significance of such a difference. However, a recent secondary analysis performed on the same population of patients suggested that both overall weight change from baseline and the difference in pattern of weight change over time were significantly lower in aripiprazoletreated patients than in patients on SOC. ${ }^{34}$ Unfortunately, the relevant information on the statistical significance of the difference in the potential incidence of clinically relevant weight gain between the groups remained uninvestigated.

More detailed information is available in a multicenter, randomized, double-blind, active-control trial in patients with schizophrenia who were in acute relapse and required hospitalization. ${ }^{35}$ At study end, a greater proportion of patients treated with olanzapine exhibited clinically significant weight gain and this difference reached statistical significance: however, these results must be interpreted with great caution because of the great percentage of patients who prematurely discontinued the trial ( $80 \%$, approximately). In fact, no decrease in the prevalence of clinically relevant weight gain was found in a recent, multicenter, double-blind study investigating effects of aripiprazole in overweight patients with schizophrenia or schizo-affective disorder switched from olanzapine. ${ }^{36}$ Moreover, a smaller and shorter study was unable to confirm potential favourable effects on bodyweight of switching patients to aripiprazole, thus suggesting this clinical and pharmacological strategy is ineffective in reducing prevalence of metabolic abnormalities in schizophrenic patients who had gained weight during treatments with other SGAs. ${ }^{37}$ In a recent study focused to evaluate feasibility of switching overweight schizophrenic patients to aripiprazole (in this study, the drug was used as either monotherapy or adjunctive therapy to clozapine or olanzapine), ${ }^{38} 6 \%$ of these patients continued to show clinically relevant weight gain; nonetheless, the mean weight loss $\mathrm{kg}$ in those who had continued aripiprazole up to study end was $3.6 \mathrm{~kg}$. Such results were consistent with those shown by a not recent, short-term trial. ${ }^{39}$ Short- and medium-term studies reporting prevalence 
rate of clinically relevant weight gain in patients treated with aripiprazole are summarized in Table 2.

\section{Long-term studies on schizophrenic/ schizoaffective patients}

A relatively large study suggested that the overall prevalence of weight gain in patients on long-term aripiprazole treatment was not different from that shown by patients chronically treated with haloperidol; ${ }^{40}$ however, patients with the lowest baseline BMI $\left(>23 \mathrm{~kg} / \mathrm{m}^{2}\right)$ experienced a significantly greater weigh gain during aripiprazole than haloperidol treatment.

Moreover, the percentage of patients who developed weigh gain in a head-to-head comparison study between aripiprazole and olanzapine was surprisingly very low in both treatment groups. ${ }^{41}$ Studies reporting the prevalence of clinically relevant weight gain during long-term aripiprazole treatment are summarized in Table 3.

\section{Short-, medium-, and long-term studies on patients with affective disorders}

A small study was recently established in order to assess the effectiveness of this medication in patients with bipolar depression were either inadequately responsive to, or poorly tolerant of, adequate treatment with at least one mood stabilizer. ${ }^{42}$ The study confirmed that patients who received aripiprazole in addition to previous treatment were at a higher risk of developing weight gain, compared with patients who continued mood stabilizing monotherapy. However, the study did not show the proportion of aripiprazole-treated patients who developed clinically relevant weight gain. In contrast, this information is available in a well-designed, 26-week study investigating the effectiveness of aripiprazole in delaying the time of disease-relapse in bipolar 1 patients in acute main phase: ${ }^{43}$ the prevalence of clinically relevant weight gain was higher in patients who received aripiprazole compared with that shown by patients randomly assigned to the placebo group. Due to statistical reasons, it was not possible to estimate the relative risk for aripiprazole/placebo. However, the only long-term study so far conducted on patients diagnosed with bipolar disorder showed that aripiprazole therapy was associated with a statistically significant increase in the risk of inducing clinically relevant gain compared with placebo. ${ }^{44}$ Only negligible proportions of patients who gained more than $7 \%$ of basal weight were reported in studies investigating the effectiveness of this drug in patients who had been hospitalized for more than $50 \%$ of the trial duration and, thus, had been on fixed dietary regimen throughout aripiprazole therapy. ${ }^{45}$

Table 2 Prevalence of clinically relevant weight gain in short/medium-term studies on schizophrenic/schizoaffective patients treated with aripiprazole

\begin{tabular}{|c|c|c|c|c|}
\hline $\begin{array}{l}\text { Study sample size }(\mathbf{N}) \\
\text { Study duration }\end{array}$ & $\begin{array}{l}\text { Percentage of } \\
\text { completers }\end{array}$ & $\begin{array}{l}\text { ARI: doses and } \\
\text { prevalence of ARI- } \\
\text { induced clinically } \\
\text { relevant weight gain }\end{array}$ & $\begin{array}{l}\text { Prevalence of } \\
\text { comparator-induced } \\
\text { clinically relevant } \\
\text { weight gain }\end{array}$ & Statistical significance \\
\hline $\begin{array}{l}\text { Potkin et al } 2003^{37}(\mathrm{~N}=202) \\
4 \text { weeks }\end{array}$ & $63.4 \%$ & $\begin{array}{l}30 \mathrm{mg} \mathrm{9 \%} \\
20 \mathrm{mg} \mathrm{I} \%\end{array}$ & $\begin{array}{l}\text { PLA 2\% } \\
\text { RIS II\% }\end{array}$ & $\begin{array}{l}\text { ARI } 20 \mathrm{mg} \text { vs PLA } p=0.004 \\
\text { ARI } 30 \mathrm{mg} \text { vs PLA } p=0.04 \\
\text { RIS } 6 \mathrm{mg} \text { vs PLA } p=0.03 \\
\text { ARI } 20-30 \mathrm{mg} \text { vs RIS } p=\mathrm{N} / \mathrm{A}\end{array}$ \\
\hline $\begin{array}{l}\text { Chan et al } 2007^{38}(\mathrm{~N}=49) \\
4 \text { weeks }\end{array}$ & $78 \%$ & $15 \mathrm{mg} 4 \%$ & RIS I $2 \%$ & $A R I I 5 \mathrm{mg}$ vs RIS $p=N S$ \\
\hline $\begin{array}{l}\text { Kane et al } 2007^{39}(\mathrm{~N}=204) \\
4 \text { weeks }\end{array}$ & $62 \%$ & $\begin{array}{l}\text { ARI I } 5 \mathrm{mg} 7 \% \\
\text { ARI } 30 \mathrm{mg} 4 \%\end{array}$ & HAL $10 \%$ & $\begin{array}{l}\text { ARI } 30 \mathrm{mg} \text { vs PLA } p=N S \\
\text { ARI } 15 \mathrm{mg} \text { vs PLA } p<0.05 \\
\text { HAL } 10 \mathrm{mg} \text { vs PLA } p<0.01 \\
\text { ARI I }-30 \mathrm{mg} \text { vs HAL } p=\text { NS }\end{array}$ \\
\hline $\begin{array}{l}\text { Kane et al } 2007^{40}(\mathrm{~N}=154) \\
6 \text { weeks }\end{array}$ & $71 \%$ & $15-30 \mathrm{mg}<2 \%$ & $\mathrm{PPH}<2 \%$ & ARI I5-30 mg vs PPH $p=N S$ \\
\hline $\begin{array}{l}\text { Kerwin et al } 2007^{4 \mid}(\mathrm{N}=284) \\
26 \text { weeks }\end{array}$ & $57.7 \%$ & $15-30 \mathrm{mg} 7 \%$ & SOC $21.2 \%$ & ARI I5-30 mg vs SOC $p=N / A$ \\
\hline $\begin{array}{l}\text { McQuade et al } 2004^{43}(\mathrm{~N}=156) \\
26 \text { weeks }\end{array}$ & $\approx 80 \%$ & $15-30 \mathrm{mg} \mid 4 \%$ & OLA $37 \%$ & ARI I5-30 mg vs OLA $p<0.001$ \\
\hline
\end{tabular}

Abbreviations: ARI, aripiprazole; OLA, olanzapine; RIS, risperidone; HAL, haloperidol; PPH, perphenazine; PLA, placebo; SOC, standard of care; N/A, data not available; NS, not statistically significant. 
Table 3 Prevalence of clinically relevant weight gain in long-term studies on schizophrenic/schizoaffective patients treated with aripiprazole

\begin{tabular}{|c|c|c|c|c|}
\hline $\begin{array}{l}\text { Study sample size }(\mathbf{N}) \\
\text { Study duration }\end{array}$ & $\begin{array}{l}\text { Percentage of } \\
\text { completers }\end{array}$ & $\begin{array}{l}\text { Prevalence of ARI- } \\
\text { induced clinically } \\
\text { relevant weight gain }\end{array}$ & $\begin{array}{l}\text { Prevalence of } \\
\text { comparator-induced } \\
\text { clinically relevant } \\
\text { weight gain }\end{array}$ & Statistical significance \\
\hline $\begin{array}{l}\text { Kasper et al } 2003^{47} \\
(N=86 I) 52 \text { weeks }\end{array}$ & $43 \%$ & $5 \%$ & HAL 3\% & $\begin{array}{l}\text { When stratified by mean body } \\
\text { mass index }(\mathrm{BMI}) \text { at the baseline } \\
\text { study visit, patients with the lowest } \\
\text { baseline } \mathrm{BMI}\left(<23 \mathrm{~kg} / \mathrm{m}^{2}\right) \text { experi- } \\
\text { enced a significantly greater weight } \\
\text { gain during aripiprazole than } \\
\text { haloperidol treatment } \mathrm{p}=\mathrm{N} / \mathrm{A}\end{array}$ \\
\hline $\begin{array}{l}\text { Chrzanowski et al } 2006^{48} \\
(\mathrm{~N}=155) \text { Up to } 72 \text { weeks }\end{array}$ & $71 \%$ & $0 \%$ & OLA 5\% & ARI I5-30 mg vs OLA $p=N / A$ \\
\hline
\end{tabular}

Abbreviations: ARI, aripiprazole; OLA, olanzapine; HAL, haloperidol; N/A, data not available.

A recent, multicenter, randomized, double-blind, placebo-controlled study investigated the effectiveness of adjunctive therapy with aripiprazole in patients diagnosed with major depressive disorder who had shown an inadequate response to at least 1 and up to 3 historical and 1 additional prospective antidepressant therapy. ${ }^{46}$ The most frequent antidepressant medications continued during the double-blind phase were escitalopram, venlafaxine extended-release, and sertraline. Despite the mean daily dose of aripiprazole being relatively low $(11.0 \mathrm{mg})$, the prevalence of clinically relevant weight gain was higher in patients who had received adjunctive therapy with this SGA than in those who had been assigned to placebo; this difference reached statistical significance. Such findings substantially replicated those that emerged from a previous, designed study. ${ }^{47}$ Short-, medium-, and long-term studies on patients with affective disorders treated with aripiprazole are shown in Table 4.

\section{Quality of life}

So far, only 4 studies investigating the impact of aripiprazole therapy on the quality of life of patients have been published. Two of these investigated the same population of patients (people enrolled in the STAR study), and 3 showed an open-label design. In the only study which provided a double-blind, placebo-controlled design, aripiprazole was merely compared with an FGA.

In the open-label study by Kerwin et al patients who had been switched to aripiprazole (because current medication was not tolerated and/or clinical symptoms were not fully controlled) showed a greater improvement in the quality of life compared with patients who remained on SOC, as

Table 4 Prevalence of clinically relevant weight gain in short/medium/long-term studies on patients with affective disorders treated with aripiprazole

\begin{tabular}{|c|c|c|c|c|}
\hline $\begin{array}{l}\text { Study sample size (N) } \\
\text { Study duration }\end{array}$ & $\begin{array}{l}\text { Psychiatric diagnosis/ } \\
\text { percentage of } \\
\text { completers }\end{array}$ & $\begin{array}{l}\text { Prevalence of ARI- } \\
\text { induced clinically } \\
\text { relevant weight gain }\end{array}$ & $\begin{array}{l}\text { Prevalence of } \\
\text { comparator-induced } \\
\text { clinically relevant } \\
\text { weight gain }\end{array}$ & Statistical significance \\
\hline $\begin{array}{l}\text { Keck et al } 2007^{51}(\mathrm{~N}=78) \\
26 \text { weeks }\end{array}$ & BID $50 \%$ & $13 \%$ & PLA 0\% & ARI I5-30 mg vs PLA $p=N / A$ \\
\hline $\begin{array}{l}\text { Keck et al } 2007^{52}(\mathrm{~N}=78) \\
\text { Up to } 72 \text { weeks }\end{array}$ & BID I8\% & $20 \%$ & PLA $5 \%$ & ARI I5-30 mg vs PLA $p=0.01$ \\
\hline $\begin{array}{l}\text { Keck et al } 2003^{53}(\mathrm{~N}=130) \\
3 \text { weeks }\end{array}$ & ABM $42 \%$ & $1.5 \%$ & PLA 0\% & ARI I5-30 mg vs PLA $p=N / S$ \\
\hline $\begin{array}{l}\text { Marcus et al } 2008^{54}(\mathrm{~N}=191) \\
6 \text { weeks }\end{array}$ & MDD $82.4 \%$ & $3.4 \%$ & PLA $0 \%$ & ARI $2-20 \mathrm{mg}$ vs PLA $\mathrm{p}=0.03 \mathrm{I}$ \\
\hline $\begin{array}{l}\text { Berman et al } 2007^{55}(\mathrm{~N}=182) \\
6 \text { weeks }\end{array}$ & MDD $87.9 \%$ & $7.1 \%$ & PLA I.2\% & ARI $2-20 \mathrm{mg}$ vs $P L A P=0.008$ \\
\hline
\end{tabular}

Abbreviations: ARI, aripiprazole; PLA, placebo; MDD, major depressive disorders; BID, bipolar I disorder; ABM, acute bipolar mania. 
demonstrated by the statistically significant changes in the Quality of Life Scale (QLS) total score. ${ }^{40}$ The QLS is a 21-item rating scale which is subdivided into 4 domains (interpersonal relations, instrumental role, intrapsychic foundations, and common objects/activities). Each of this domain is scored on a 7-item scale, with the lowest score indicating the most severe degree of dysfunction. ${ }^{48}$ However, as Table 5 shows, the overall discontinuation rate for either lack of efficacy and/or adverse events was higher in patients who had been switched to aripiprazole treatment than that shown by patients who had continued the previous pharmacological regimen. A post-hoc analysis conducted on the same population of patients investigated other aspects of quality of life of these schizophrenic patients, including a generic measurement of health-related quality of life, through specific instruments such as the EuroQol-5D (EQ-5D). ${ }^{49}$ This is a simple, 5-item scale which assesses mobility, self-care, usual activity, pain/discomfort, and anxiety/depression..$^{50} \mathrm{At}$ study end (week 26), patients who started aripiprazole treatment and those continuing SOC showed substantially similar values at the Q-5D (see Table 5). In contrast, as shown in Table 5, the addition of aripiprazole to clozapine induced a statistically significant improvement in the global QLS score in a the third open-label study. ${ }^{51}$

On the other hand, the only double-blind, randomized study which attempted to compare changes in quality of life among patients on aripiprazole or perphenazine treatment failed to demonstrate any statistically significant differences between the groups ${ }^{39}$ (see Table 5). In fact, in this study the mean changes in QLS score from baseline were similar in both groups. Moreover, the Authors reported that the proportion of patients experiencing a clinically important improvement ( $\geq 20 \%$ increase in QLS score from baseline) in QLS was higher in the aripiprazole group (36\%) than in the perphenazine group (21\%). In any case, this result (emerging from data from both completers and non-completers [Last Observation Carried Forward methodology]), did not indicate any statistical relevance.

\section{Discussion}

\section{Weight gain}

As regards the liability of aripiprazole to inducing weight gain, short/medium-term studies on schizophrenic or schizoaffective patients (showing a range of duration between 4 and 26 weeks) demonstrated that the prevalence rate of clinically relevant weight gain during therapy with this drug is similar to that occurring during treatments with other antipsychotic agents, either typical (haloperidol, perphenazine ${ }^{38,39}$ ) or atypical (risperidone ${ }^{37}$ ), and even higher than that occurring in patients included in placebo control-groups. ${ }^{37}$ The finding that the proportion of aripiprazole-treated patients who may develop clinically relevant weight gain is lower than that recorded in patients continuing standard of care (specifically, olanzapine, risperidone, and olanzapine) has no relevance in clinical practice, because no head-to-head comparison had been performed between aripiprazole and each of these SGAs. ${ }^{40}$ In addiction, the strength of conclusions emerging from the only available head-to-head comparison with olanzapine (aripiprazole was less likely to induce clinically relevant weight gain than olanzapine) is impaired by the high percentage of patients who prematurely discontinued this trial (80\%, approximately). ${ }^{43}$ In fact, this difference seemed to disappear in a further, long-term study. ${ }^{49}$ Moreover, longterm studies suggested that patients with low baseline BMI are at greater risk of developing an increase in bodyweight during chronic aripiprazole treatment than during chronic

Table 5 Changes in quality of life in patients treated with aripiprazole

\begin{tabular}{|c|c|c|c|c|}
\hline $\begin{array}{l}\text { Study sample size }(\mathbf{N}) \\
\text { Study duration }\end{array}$ & $\begin{array}{l}\text { Discontinuation rate } \\
\text { for lack of efficacyl } \\
\text { adverse events in the } \\
\text { ARI-group }\end{array}$ & $\begin{array}{l}\text { Discontinuation rate } \\
\text { for lack or efficacy- } \\
\text { adverse events in the } \\
\text { comparator group }\end{array}$ & $\begin{array}{l}\text { Improvement in the } \\
\text { quality of life between } \\
\text { the groups and statistical } \\
\text { significance }\end{array}$ & $\begin{array}{l}\text { Standardized } \\
\text { instruments } \\
\text { used }\end{array}$ \\
\hline $\begin{array}{l}\text { Kerwin et al } 2007^{40}(\mathrm{~N}=284) \\
26 \text { weeks }\end{array}$ & $53.9 \%$ & $46.1 \%$ & $A R I>S O C p<0.00 I$ & QLS \\
\hline $\begin{array}{l}\text { Taylor et al } 2008^{56} \text { (Same } \\
\text { population and duration of } \\
\text { the Kerwin's study) }\end{array}$ & $\begin{array}{l}\text { Same population and } \\
\text { duration of the Kerwin's } \\
\text { study }\end{array}$ & $\begin{array}{l}\text { Same population and } \\
\text { duration of the Kerwin's } \\
\text { study }\end{array}$ & $\mathrm{ARI}=\mathrm{SOC}$ & EQ-5D \\
\hline $\begin{array}{l}\text { Mitsonis et al } 2007^{58}(\mathrm{~N}=27) \\
16 \text { weeks }\end{array}$ & $7.4 \%$ & N/A & $\begin{array}{l}\text { ARI plus CLO }>\text { CLO } \\
\mathrm{P}<0.05\end{array}$ & QLS \\
\hline $\begin{array}{l}\text { Kane et al } 2007^{39}(\mathrm{~N}=154) \\
16 \text { weeks }\end{array}$ & $32 \%$ & $19 \%$ & $A R I=P P H$ & QLS \\
\hline
\end{tabular}

Abbreviations: ARI, aripiprazole; SOC, standard of care; PPH, perphenazine; QLS, Quality of Life Scale; EQ-5D, EuroQol-5D; N/A, data not available. 
haloperidol treatment. ${ }^{48}$ The absence of neutrality on weight changes shown by aripiprazole seems to be especially manifest when the drug is used as medium/long-term therapy in patients with affective disorder: in this specific psychiatric population, the proportion of patients who may incur iatrogenic metabolic complications could indeed range between $13 \%$ and $20 \% .^{51,52}$

\section{Quality of life}

Although quality of life is important for patients with schizophrenia, it is difficult to determine due to the fact that it relies on patient perception and self-evaluation, which is likely to be impaired by the underlying condition. Moreover, beyond the methodological limitations shown by studies specifically focused on aripiprazole, until now there continues to be a lack of agreement on definitions of the concept of quality of life $\mathrm{e}^{52}$ (see Table 6). In fact, quality of life is defined in multiple ways and means different things to different people. These various ways of defining quality of life range from vague definitions of "whatever the individual defines it to be," "ability to lead a normal life" and "self-actualization," to more thoughtful and considered definitions such as those that emphasize fulfillment of personal goals. ${ }^{53}$ In any case, data on the impact of aripiprazole therapy on the quality of life of schizophrenic patients are scarce and characterized by conflicting results. ${ }^{39,40,56,58}$ In addiction, until now studies lasting more than 26 weeks are unavailable. Our results substantially replicate those emerging

Table 6 The concept of quality of life over the years ${ }^{67,68,69,70,71,72}$

\begin{tabular}{|c|c|}
\hline Author(s) and year & Definitions \\
\hline Calman $1984^{62}$ & $\begin{array}{l}\text { "The gap between the patient's expectations } \\
\text { and achievements." }\end{array}$ \\
\hline Ware $1984^{63}$ & $\begin{array}{l}\text { "The result of the hierarchic interaction } \\
\text { between medical illness, psychological } \\
\text { distress, personal, social, and role functioning, } \\
\text { subjective feeling of well-being, overall health } \\
\text { perceptions." }\end{array}$ \\
\hline $\begin{array}{l}\text { Wood-Dauphinee and } \\
\text { Williams } 1987^{64}\end{array}$ & $\begin{array}{l}\text { "The quality of patient's integration into } \\
\text { normal living." }\end{array}$ \\
\hline Hørnquist $1989^{65}$ & $\begin{array}{l}\text { "The degree of need satisfaction within the } \\
\text { areas of the physical, psychological, social, } \\
\text { activity, material and structural needs." }\end{array}$ \\
\hline Ferrans $1990^{66}$ & $\begin{array}{l}\text { "A person's sense of well-being that stems } \\
\text { from satisfaction or dissatisfaction with the } \\
\text { areas of life that are important to him/her." }\end{array}$ \\
\hline WHO $1998^{66}$ & $\begin{array}{l}\text { "The individuals' perceptions of their position } \\
\text { in life, in the context of the cultural and value } \\
\text { systems in which they live and in relation } \\
\text { to their goals, expectations, standards and } \\
\text { concerns." }\end{array}$ \\
\hline
\end{tabular}

from unpublished data and reported in the systematic review by El-Sayeh and Morganti, who revealed no conclusive evidence of a clinically important improvement in quality of life among 154 patients given aripiprazole, as assessed by the QLS. ${ }^{54}$ These findings are not surprising.

\section{Conclusions}

The specific receptorial affinity of aripiprazole and, thus, its mechanisms for action, both have led to the hypothesis that medication could be considered as an interesting, safe, and effective medication in the psychopharmacological armamentarium against SPMDs compared with other antipsychotic agents. Unfortunately, however, the enthusiasm which accompanied the introduction of the drug onto market should be attenuated. In fact, a part from the relevant concerns which seem to negate the theorized neutral effects on bodyweight and the positive impact on the quality of life, other possible advantages of the unique pharmacodynamic properties of aripiprazole remain doubtful. ${ }^{55}$

In fact, despite the peculiar activity of aripiprazole at $\mathrm{D}_{2}$ receptors ( associated with both reduced neurocognitive effects and an improved neurological tolerability). ${ }^{56,57,58}$ it has been conversely suggested that there are no beneficial effects of aripiprazole on general cognitive and executive functioning. ${ }^{19}$ Moreover, data emerging from either short- or long-term studies also questions the neurological safety of aripiprazole which, at least in bipolar patients, seems not to be devoid of risk inducing EPS. ${ }^{59}$ In the light of these considerations, we are forced to conclude that evidence-based information indicates that further, well-designed studies are needed before confirming, if existing, potential advantages of aripiprazole over FGAs and other SGAs.

\section{Disclosures}

The author discloses no conflicts of interest.

\section{References}

1. Davies LM, Drummond MF. The economic burden of schizophrenia. Psychiatr Bull. 1990;14:522-555.

2. Murray CJ, Lopez AD. Evidence-based health policy: lessons from the Global Burden of Disease Study. Science. 1996;274:740-743.

3. Bunney WE, Meltzer HY. Schizophrenia: overview. Clin Neurosci. 1995;3:55-56.

4. Keck PE Jr, McElroy SL, Arnold LM. Bipolar disorder. Med Clin North Am. 2001;85:645-661.

5. Angst J. The emerging epidemiology of hypomania and bipolar II disorder. $J$ Affect Disord. 1998;50:143-151.

6. Prevalence and incidence of bipolar disorder [homepage on the Internet]. Available from: www.wrongdiagnosis.com/b/bipolar/prevalence.htm. Accessed September 11, 2008.

7. Gentile S. Extrapyramidal adverse events associated with atypical antipsychotic treatment of bipolar disorder. J Clinical Psychopharmacol. 2007;27:35-45. 
8. Meltzer HY. The role of serotonin in antipsychotic drug action. Neuropsychopharmacology. 1992;21(2 suppl):S106-S115.

9. Kapur S, Seeman P. Antipsychotic agents differ in how fast they come off the dopamine $\mathrm{D}_{2}$ receptors: implication for atypical antipsychotic action. J Psychiatry Neurosci. 2000;25:161-166.

10. Kapur S, Seeman P. Does fast dissociation from the dopamine $\mathrm{D}_{2}$ receptor explain the action of atypical antipsychotics? Am J Psychiatry. 2001;158:360-369.

11. Seeman P, Tallerico T. Antipsychotic drugs which elicit little or no parkinsonism bind more loosely than dopamine to brain $\mathrm{D}_{2}$ receptors, yet occupy high levels of these receptors. Mol Psychiatry. 1998;3:123-134.

12. Gentile $\mathrm{S}$. Atypical antipsychotic for the treatment of bipolar disorder. More shadows than lights. CNS Drugs. 2007;21:367-387.

13. Gentile S. Long term atypical antipsychotics treatment and risk of weight gain. A literature analysis. Drug Saf. 2006;29:303-319.

14. Aichhorn W, Whitworth AB, Weiss EM, Marksteiner J. Secondgeneration antipsychotics: is there evidence for sex differences in pharmacokinetic and adverse effect profiles? Drug Saf. 2006;29(7):587-598.

15. Fleishhacker WW, Meise U, Gunther V, Kurz M. Compliance with antipsychotic drug treatment: influence of side effects. Acta Psychiatr Scand. 1994;382(suppl):S11-S15.

16. Gentile S. Antipsychotic-associated weight gain. Ann Pharmacother. 2004:38:903-904

17. Jordan S, Koprivica V, Chen R, Tottori K, Kikuchi T, Altar A. The antipsychotic aripiprazole is a potent, partial agonist at human 5-HT1A receptor. Eur J Pharmacol. 2002;441:137-140.

18. Reynolds GP. Antipsychotic drug mechanisms and neurotransmitter systems in schizophrenia. Acta Psychiatr Scand. 1994;380(suppl):36-40.

19. Argo TR, Carnahan RM, Perry PJ. Aripiprazole, a novel antipsychotic drug. Pharmacotherapy. 2004;24:212-228.

20. Brixner DI, Said Q, Corey-lisle PK, et al. Naturalistic impact of second-generation antipsychotics on weight gain. Ann Pharmacother. 2006;40:626-632.

21. Raddymasu S, Bahta E, Levin S, Manas K, Slay LE. Elevated lipase and diabetic ketoacidosis associated with aripiprazole. J Pancreas. 2006;7:303-305.

22. Allison DB, Mackell JA, McDonnell DD. The impact of weight gain on quality of life among persons with schizophrenia. Psychiatr Serv. 2003;54:565-567.

23. Jones PB, Barnes TRE, Davies L, et al. Randomized controlled trial of the effect on quality of life of second- vs first-generation antipsychotic drugs in schizophrenia. Cost utility of the latest antipsychotic drugs in schizophrenia study (CUtLASS 1). Arch Gen Psychiatry. 2006;63:1079-1087.

24. Nemeroff CB. Safety of available agents used to treat bipolar disorder: focus on weight gain. J Clin Psychiatry. 2003;64:532-539.

25. Weiden PJ, Mackell JA, McDonnell DD. Obesity as risk factor for antipsychotic noncompliance. Schizophr Res. 2004;66:51-57.

26. Newcomer JW. Second-generation (atypical) antipsychotics and metabolic effects. A Comprehensive literature review. CNS Drugs. 2005;19(suppl 1):1-93.

27. Haddad P. Weight change with atypical antipsychotics in the treatment of schizophrenia. J Psychopharmacol. 2005;19(suppl):16-27.

28. Álvarez-Jiménez M, Gonzáles-Blanch C, Crespo-Facorro B, et al. Antipsychotic-induced weight gain in chronic and first-episode psychotic disorders. A systematic critical reappraisal. CNS Drugs. 2008;22:547-562.

29. Potkin SG, Saha AR, Kujawa MJ, et al. Aripiprazole, an antipsychotic with a novel mechanism of action, and risperidone vs placebo in patients with schizophrenia and schizoaffective disorder. Arch Gen Psychiatry. 2003;60:681-690.

30. Chan HY, Lin WW, Lin SK, et al. Efficacy and safety of aripiprazole in the acute treatment of schizophrenia in Chinese patients with risperidone as an active control: a randomized trial. J Clin Psychiatry. 2007;68:29-36.

31. Kane JM, Carson WH, Saha AR, et al. Efficacy and safety of aripiprazole and haloperidol versus placebo in patients with schizophrenia and schizoaffective disorder. J Clin Psychiatry. 2007;63:763-771.
32. Kane JM, Meltzer HY, Carson WH, for the aripiprazole Study Group. Aripiprazole for treatment-resistant schizophrenia: results of a multicenter, randomized, double-blind, comparison versus perphenazine. J Clin Psychiatry. 2007;68:213-223.

33. Kervin R, Millet B, Herman E, et al. A multicentre, randomized, naturalistic, open-label study between aripiprazole and standard of care in the management of community-treated schizophrenic patients Schizophrenia Trial of Aripiprazole: (STAR) study. Eur Psychiatry. 2007;22:433-443.

34. Kolotkin RL, Corey-Lisley PK, Crosby RD, Kan HJ, McQuade RD. Changes in weight and weight-related quality of life in a multicentre, randomized trial of aripiprazole versus standard of care. Eur Psychiatry. 2008 [Epub ahead of print].

35. McQuade RD, Stock E, Marcus R, et al. A comparison of weight change during treatment with olanzapine or aripiprazole: results from a randomised, double-blind trial. J Clin Psychiatry. 2004;65(suppl 18):47-56.

36. Newcomer JW, Campos JA, Marcus RN, et al. A multicenter, randomized, double-blind study of the effects of aripiprazole in overweight subjects with schizophrenia or schizoaffective disorder switched from olanzapine. J Clin Psychiatry. 2008;69:1046-1056.

37. Kim SH, Ivanova O, Abbasi FA, Lambendola CA, Reaven GM, Glick ID. Metabolic impact of switching antipsychotic therapy to aripiprazole after weight gain. J Clin Psychopharmacol. 2007;27:365-368.

38. Schorr SG, Slooff CJ, Postema R, et al. A 12-month follow-up study of treating overweight schizophrenic patients with aripiprazole. Acta Psychiatr Scand. 2008;118:246-250.

39. Casey DE, Carson WH, Saha AR, Liebeskind A, Ali MW, Jody D. Switching patients to aripiprazole from another antipsychotic agent: a multicenter randomized study. Psychopharmacology. 2003;166:391-399.

40. Kasper S, Lerman MN, McQuade RD, et al. Efficacy and safety of aripiprazole vs. haloperidol for long-term maintenance treatment following acute relapse of schizophrenia. Int $J$ Neuropsychopharmacol. 2003;6:325-337.

41. Chrzanowski WK,M arcus RN, Torbeyns A, Nyilas M. Effectiveness of long-term aripiprazole therapy in patients with acutely relapsing or chronic, stable schizophrenia: a 52-week, open-label comparison with olanzapine. Psychopharmacology. 2006;189:259-266.

42. McElroy S, Suppes T, Frye MA, et al. Open-label aripiprazole in the treatment of acute bipolar depression: a prospective pilot trial. $J$ Affect Disord. 2007;101:275-281.

43. Keck PE, Calabrese JR, McQuade RD, et al. A randomized, doubleblind, placebo-controlled 26-week trial of aripiprazole in recently manic patients with bipolar I disorder. J Clin Psychiatry. 2006;67:626-637.

44. Keck PE, Calabrese JR, McIntyre RS, et al. Aripiprazole monotherapy for maintenance therapy in bipolar I disorder: a 100-week, double-blind study versus placebo. J Clin Psychiatry. 2007;68:1480-1491.

45. Keck PE Jr, Marcus R, Tourkodimitris S, Ali M, Liebeskind A, Saha A, Ingenito G; Aripiprazole Study Group. A placebo-controlled, doubleblind study of the efficacy and safety of aripiprazole in patients with acute bipolar mania. Am J Psychiatry. 2003;160(9):1651-1658.

46. Marcus RN, McQuade RD, Carson WH, et al. The efficacy and safety of aripiprazole as adjunctive therapy in major depressive disorder. A second multicenter, randomized, double-blind, placebo-controlled study. J Clin Psychopharmacol. 2008;28:156-165.

47. Berman RM, Marcus RN, Swanink R, et al. The efficacy and safety of aripiprazole as adjunctive therapy in major depressive disorder: a multicenter, randomized, double-blind, placebo-controlled study. J Clin Psychiatry. 2007;68:843-853.

48. Heinrichs DW, Hanlon TE, Carpenter Jr WT. The Quality of Life Scale: an instrument for rating the schizophrenic deficit syndrome. Schizophr Bull. 1984;10:388-398.

49. Taylor D, Hanssens L, Loze JY, Pans M, L'Italien G, Marcus RN. Preference of medicine and patient-reported quality of life in communitytreated schizophrenic patients receiving aripiprazole vs standard of care. Results from the STAR study. Eur Psychiatry. 2008;23:336-343.

50. EuroQol Group. EuroQol-a new facility for the measurement of healthrelated quality of life. Health Policy. 1990;16:199-208. 
51. Mitsonis CI, Dimopoulos NP, Mitropoulos PA, Kararizou EG, Katsa AN, Tsakiris FE. Aripiprazole augmentation in the management of residual symptoms in clozapine-treated outpatients with chronic schizophrenia: an open-label pilot study. Prog Neuropsychopharm Biol Psychiatry. 2007;31:373-377.

52. Awad AG, Voruganti LNP. Impact of atypical antipsychotics on quality of life in patients with schizophrenia. CNS Drugs. 2004;18:877-893.

53. Quality of life compendium. Center for Quality of Life Research in Nursing Science Section for Nursing Science, Department of Public Health and Primary Health Care, University of Bergen .[homepage on the Internet]. Available from URL: http://www.uib.no/isf/people/doc/ qol/httoc.htm. Accessed: 14 November 2008.

54. El-Sayeh HG, Morganti C. Aripiprazole for schizophrenia (review). Cochrane Database Syst Rev. 2004;2:CD004578.pub2.

55. Wirshing D, Wirshing A. Aripiprazole. A viewpoint. CNS Drugs. 2002;16:787-788.

56. McGavin JK, Goa KL. Aripiprazole. CNS Drugs. 2002;16:779-786.

57. Benkert O, Müller-Siecheneder F, Wetzel H. Dopamine agonists in schizophrenia: a review. Eur Neuropsychopharmacol. 1995; 5(suppl):43-53.

58. Kasper S, Barnas C, Heiden A. Pramipexole as adjunct to haloperidol in schizophrenia: safety and efficacy. Eur Neuropsychopharmacol. 1997;7:65-70

59. Gentile S. Extrapyramidal adverse events associated with atypical antipsychotic treatment of bipolar disorder. J Clin Psychopharmacol. 2007;27:35-45.

60. Burris KD, Molski TF, Ryan E, et al. Aripiprazole is a high affinity partial agonist at human dopamine $\mathrm{D}_{2}$ receptors. Int J Neuropsychopharmacol. 2000;3(supp1 1):S129.

61. Shapiro DA, Renock S, Arrington S, et al. Aripiprazole, a novel atypical antipsychotic drug with a unique and robust pharmacology Neuropsychopharmacology. 2003;28:1400-1411.
62. Stark AD, Jordan S, Allers KA, et al. Interaction of the novel antipsychotic aripiprazole with 5-HT(1A) and 5-HT(2A) receptors: functional receptor-binding and in vivo electrophysiological study. Psychopharmacology (Berl.). 2007;190:373-382.

63. Keck PE, McElroy SL. Aripiprazole: a partial dopamine D2 receptor agonist antipsychotic. Expert Opin Invest Drugs. 2003;12:655-662.

64. Food and Drug Administration Center for Drug Evaluation and Research [homepage on the Internat]. Application number 21-436. Clinical pharmacology and biopharmaceutics review(s). Available from http://www.fda.gov/cder/foi/nda/2002/21-436_Abilify.htm. Accessed: September 11, 2008

65. Active ingredient: Aripiprazole - Basic Profile / Key Facts [homepage on the Internet]. Available from URL: http://www.druglib.com/activeingredient/aripiprazole/. Accessed September 11, 2008.

66. Lawler, CP, Prioleau, C, Lewis MM, et al. Interactions of the novel antipsychotic aripiprazole (OPC-14597) with dopamine and serotonin receptor subtypes. Neuropsychopharmacology. 1999;20:612-627.

67. Calman KC, Quality of life in cancer patients: a hypothesis. $J$ Med Ethics. 1984:10:124-127.

68. Ware JE. Conceptualizing disease impact and treatment outcome. Cancer. 1984;53:2316-2323.

69. Wood-Dauphinee S, Williams JL. Reintegration in normal living as a proxy to quality of life. J Chronic Dis. 1987;40:491-502.

70. Hornquist J-O. Quality of life: concept and assessment. Scand J Soc Med. 1989;18:69-79.

71. Ferrans CE. Quality of life: conceptual issues. Sem Oncol Nurs. 1990; 6:248-254.

72. Kalfoss MH, Ringel, KS, Gundersen V (1998). the World Health Organization's Quality of Life Assessments (WHOQOL - 100 and WHOQOL - brief) knowledge development: clinicians and researchers in partnership. Proceedings from the 9th Biennial Conference and Workshop of European Nurse Researchers, July 5-8, 1998, Helsinki, p. 376-387. 
